\title{
A NEW SPERMDENSIMETER TO DETERMINE THE SPERM CONCENTRATION OF EQUINE SEMEN
}

(Novo espermiodensímetro para determinar a concentração espermática do sêmen equino)

Luis Gustavo Freitag de Lima https://orcid.org/0000-0003-2186-9461, Giovanna Polo Freitag https://orcid.org/0000-0002-

4771-1243, Luiz Ernandes Kozickihttps://orcid.org/0000-0002-3700-1811

Pontifícia Universidade Católica do Paraná, PR, Brasil.

${ }^{1}$ Corresponding author: luisfreitag@gmail.com

\begin{abstract}
This study aimed to develop a spermdensimeter for evaluating stallion semen in a practical and efficient manner. This method is an alternative to the standard method that utilizes a Neubauer chamber under field conditions, which is typically employed because the Karras spermdensimeter ${ }^{\circledR}$ model (for bovine and swine) is not suitable for determining equine semen concentrations. Two spermdensimeter models were developed. The appliances were made out of acrylic material, and each one had different angulations, with $8^{\circ}$ for Model $A$ and $10^{\circ}$ for Model B. We tested 123 semen samples from stallions to evaluate and calibrate the two spermdensimeter prototypes based on the Neubauer chamber. Samples were analyzed by two evaluators. These results were compared to those obtained using the Neubauer chamber. Linear regression was used to establish the scale of concentrations for each model. Additionally, the correlation between the scales and the values found using the Neubauer chamber was calculated. Linear regression demonstrated a precise adjustment for the concentration curves, resulting in $r^{2}=$ 0.9395 for Model A and $r^{2}=0.9418$ for Model B. The correlations for the concentrations were significant $(p<0.0001)$. They were high and negatively correlated, measuring -0.83 for Model $A$ and -0.8 for Model B. We concluded that the spermdensimeters we developed were effective for evaluating stallion sperm concentrations. These models can be used in routine practices associated with equine reproduction, achieving the main purpose of this work.
\end{abstract}

Keywords: Neubauer; practical; reproduction; stallion.

RESUMO - Este estudo teve por objetivo desenvolver um espermiodensímetro para avaliar o sêmen de garanhões de maneira prática e eficiente. Este método é uma alternativa ao método padrão que usa a câmara de Neubauer para condições de campo, que é normalmente utilizado pois o modelo de espermiodensímetro de Karras $^{\circledR}$ (para bovinos e suínos) não é apropriado para determinar a concentração de sêmen equino. Dois modelos de espermiodensímetro foram desenvolvidos. Os aparelhos foram feitos de material acrílico e cada um com diferentes angulações, sendo $8^{\circ}$ para o Modelo A e $10^{\circ}$ para o Modelo B. Foram testadas 123 amostras de sêmen de garanhões para avaliar e calibrar os dois protótipos de espermiodensímetro baseando-se na câmara de Neubauer. As amostras foram avaliadas por dois avaliadores. Estes resultados foram comparados aos obtidos 
usando a câmara de Neubauer. Regressão linear foi utilizada para estabelecer as escalas de concentração para cada modelo. Adicionalmente, a correlação entre as escalas e os valores de concentração obtidos usando a câmara de Neubauer foram calculadas. A regressão linear demonstrou um ajuste preciso para as curvas de concentração, resultando em $r^{2}=0.9395$ para o Modelo $A$, e $r^{2}=0.9418$ para o Modelo B. As correlações para as concentrações foram significativas $(p<0.0001)$. Elas foram altas e negativamente correlacionadas, medindo -0.83 para o Modelo $A$ e - 0,8 para o Modelo B. Portanto, essa relação foi inversamente proporcional. Nós concluímos que os espermiodensímetros que desenvolvemos foram efetivos para avaliação de concentrações de sêmen de garanhões. Estes modelos podem ser usados em práticas rotineiras associadas à reprodução equina, alcançando o objetivo principal deste trabalho.

Palavras-chave - garanhões; Neubauer; prática; reprodução.

\section{INTRODUCTION}

The use of reproductive biotechnology has contributed to accelerated genetic improvements by increasing the fertility of the equine species. This has been particularly important because horses have lower fertility rates than those of other livestock (Noakes et al., 2001; Nath, 2011). Currently, the most commonly used equine biotechnology techniques are artificial insemination (Al) and embryo transfer (Estrada and Samper, 2007). Al increases the genetic quality of the herd by allowing the producer to utilize semen from the best stallions, which is economically advantageous (Nath, 2011). Pregnancy rates among stallions depend not only on individual genetic variation but also on the technique and semen manipulation (Nunes et al., 2006). Among the factors that can affect reproductive performance is seminal quality (Guasti et al., 2012), which can be evaluated for macroscopic characteristics including volume, color, viscosity, and appearance using semen collection (Nath, 2011; Griffin, 2000). The concentration of semen used for breeding is another characteristic to be considered. The evaluation must be accurate, aiming to increase the reproductive efficiency of an Al program (Vianna et al., 2004), particularly when the purpose is to use the ejaculate to inseminate a large number of mares (Conboy, 2011).

In bovine reproduction, the most commonly used methods to determine sperm concentrations are the Neubauer chamber, spermdensimeter, and spectrophotometer. The Karras spermdensimeter ${ }^{\circledR}$ is considered more advantageous compared to the other techniques due to its low cost and high efficiency for use in cattle and pigs. In swine, the spermdensimeter is routinely used and has been compared to other methods, such as the Neubauer chamber and spectrophotometer. However, this method has advantages and disadvantages (Vianna et al., 2004, Murgas et al., 2010). Despite its practicality and worldwide use in cattle (Barbosa et al., 2011) and pigs (Vianna et al., 2004, Murgas et al., 2010), the Karras ${ }^{\circledR}$ sperdensimeter cannot correctly estimate stallion sperm concentration. In field trials using different stallions, it was shown (unpublished data, 2013) that when the ejaculate contained low sperm concentrations (even if this was still within the standards for the species), it is not possible to obtain a visual reading using the Karras spermdensimeter. This is because it was originally designed for use on bull semen (for which the sperm concentration ranges from 800 to 2000 million sperm $/ \mathrm{mL}$ ) or for boar semen (for which the sperm concentration ranges from 200 to 
300 million sperm $/ \mathrm{mL}$ ) (Garner and Hafez, 2004). Although the boar sperm concentration is close to that of the stallion (150 to 300 million sperm $/ \mathrm{mL}$ ) (Garner and Hafez, 2004), a wide variation in individual sperm concentrations (between 50 and 400 million spermatozoa/mL) has been observed in stallion ejaculates (Love, 2007).

Therefore, different spermdensimeter prototypes were created to determine the most suitable and consistent design. The initial idea involved having more space between the walls by increasing the angle, allowing a greater number of spermatozoa (sperm plus water) to occupy the space within the front and back walls. This would enable the measurement of stallion sperm concentrations via a turbidity reading. Thus, the hypothesis of the present study is that the spermdensimeters developed in this study are able to measure the concentration of spermatozoa in stallion semen.

The present study aimed to develop spermdensimeters that are capable of quickly and efficiently evaluate the concentration of sperm in stallion semen in field conditions.

\section{MATERIAL AND METHODS}

The spermdensimeter prototypes developed for this study were similar in form to the Karras spermdensimeter ${ }^{\circledR}$ because they were acrylic, which is a clear and colorless material. The prototypes also had a scale on the back of the bottle, which numbered from 1 to 10 with an interval of $0.5 \mathrm{~cm}$. Different from the spermdensimeters used for cattle and pigs, the prototypes had a support base, which provided a flat surface for them to support themselves. Another difference from the Karras spermdensimeter ${ }^{\circledR}$ was the internal angles, being $8^{\circ}$ and $10^{\circ}$ for Model $A$ and Model $B$, respectively. Both devices required a dilution of $1 \mathrm{~mL}$ of semen in $10 \mathrm{~mL}$ of water, with a total of $11-\mathrm{mL}$ solution. This solution also required homogenization before use. Measurements were made in a similar manner as the Karras spermdensimeter ${ }^{\circledR}$. Briefly, both spermdensimeter prototypes were held by the base by the observer with their arm outstretched. The device was held against a white, illuminated wall. Readings were obtained by determining the number at which the solution appeared turbid and become difficult to visualize. The numbers printed on the back of the device provided these readings, which ranged from 1 to 10 (Figure 1). High semen concentrations tend to cloud at lower values closer to label 1, whereas lower semen concentrations tend to cloud closer to 10. 


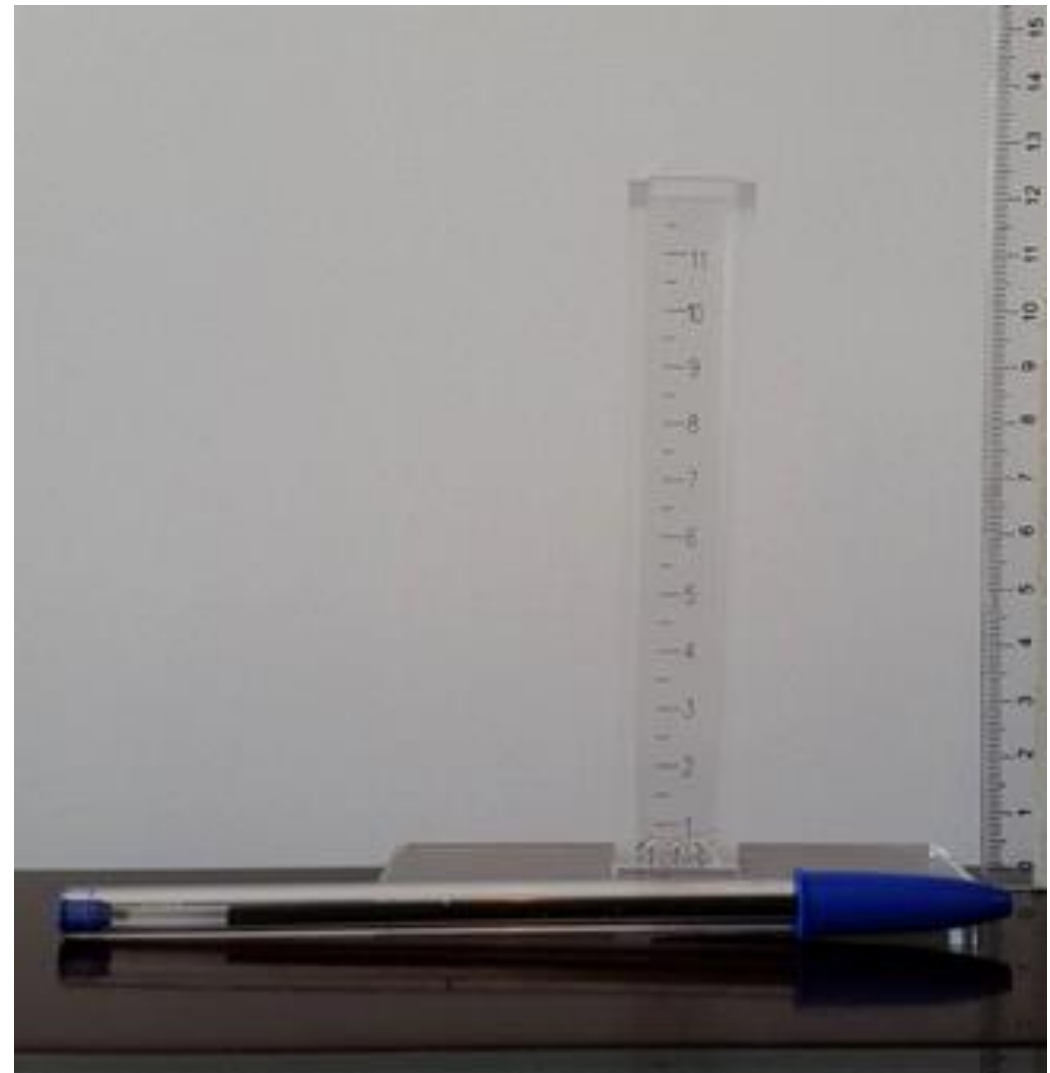

Figure 1 - Spermdensimeter with a scale printed on the back wall and a graduated ruler and a pen as reference for model dimensions.

Samples of semen $(n=123)$ from forty 3- to 20-year-old Crioulo, Quarter Horse, and Appaloosa stallions were collected using an artificial vagina (Conboy, 2011). The animals lived on stud farms in Curitiba, which was located at 25 $2540 \mathrm{~S}$ and 49 16230 in Paraná, Brazil. Animals were fed tifton hay, alfalfa, and water ad libitum. Concentrated ration was supplied according to individual horse's needs. The animals were kept in the stalls during the night and subsequently roamed free in the paddocks during the day. Sample collections were performed within 1 year, both during and after the reproductive season. After semen collection, the gelatinous fraction was separated using a semen filter. The samples were subsequently packed in 15-mL Falcon-type tubes to be transported to the laboratory for sperm concentration analysis using the Neubauer chamber (CBRA, 1998) and the spermdensimeter prototypes. B (Figure 2).

First, the samples were evaluated using spermdensimeter Model A and Model 


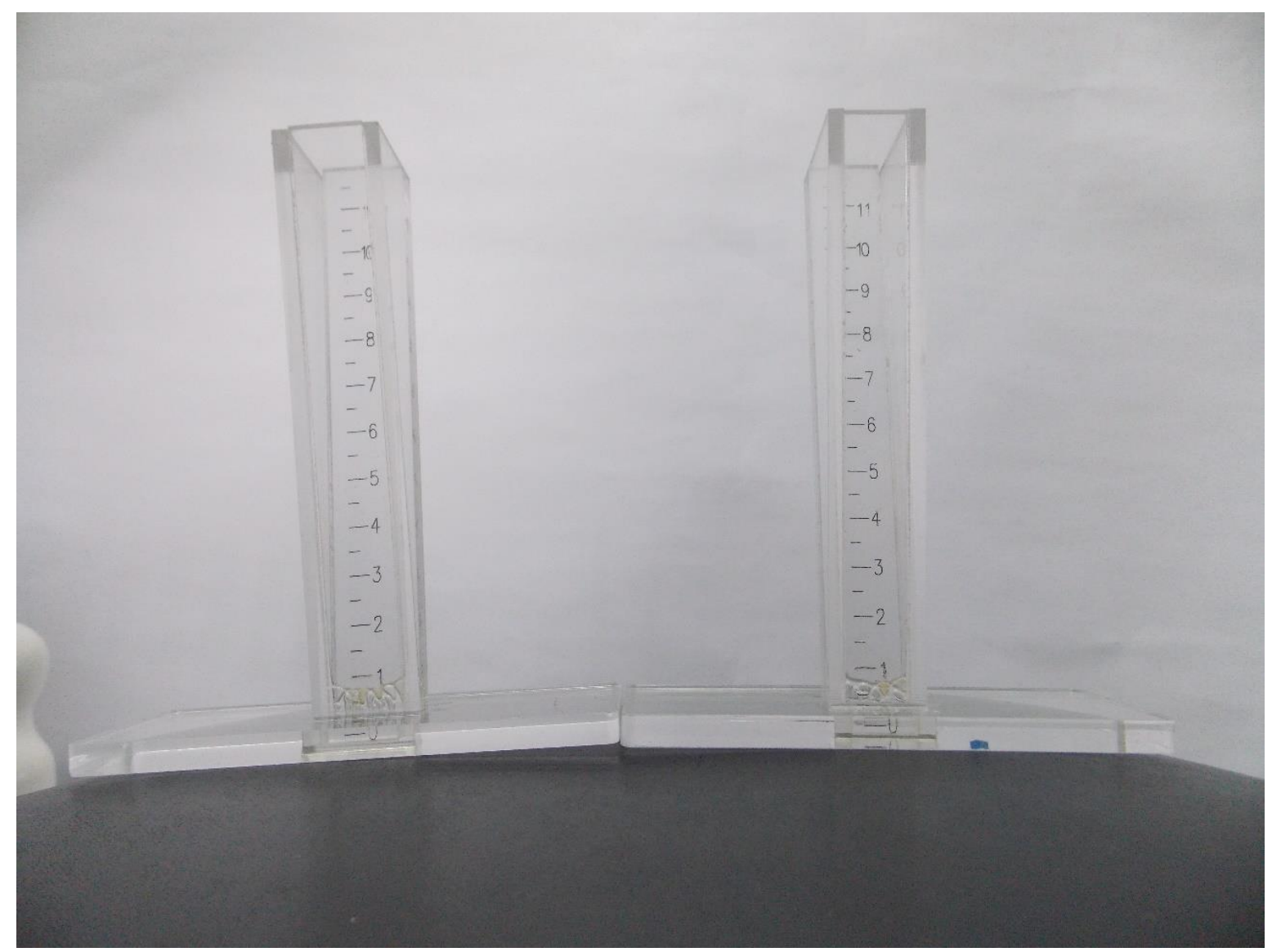

Figure 2 - Spermdensimeter prototypes developed for equine semen Models A (left, internal angle of $8^{\circ}$ ) and $\mathrm{B}$ (right, internal angle of $10^{\circ}$ ).

The methodology for performing spermdensimeter measurements (Figure 3 ) comprised making a dilution of $1 \mathrm{~mL}$ of semen in $10 \mathrm{~mL}$ of distilled water inside the device, with a total of $11-\mathrm{mL}$ solution. The solution was subsequently homogenized within the apparatus by capping the upper opening with the thumb and turning the bottle downward and upward with slight movements. After homogenization, the evaluator positioned himself approximately 1.0 meter from a white surface (a wall) and held the spermdensimeter $70 \mathrm{~cm}$ away from his body directed toward the white surface in an artificially lit environment (Figure 4). The solution was considered to be turbid where the number started to lose sharpness. This measurement was obtained by observing the solution from the bottom up and recording the number on the scale where turbidity was visualized (Figure 5). 


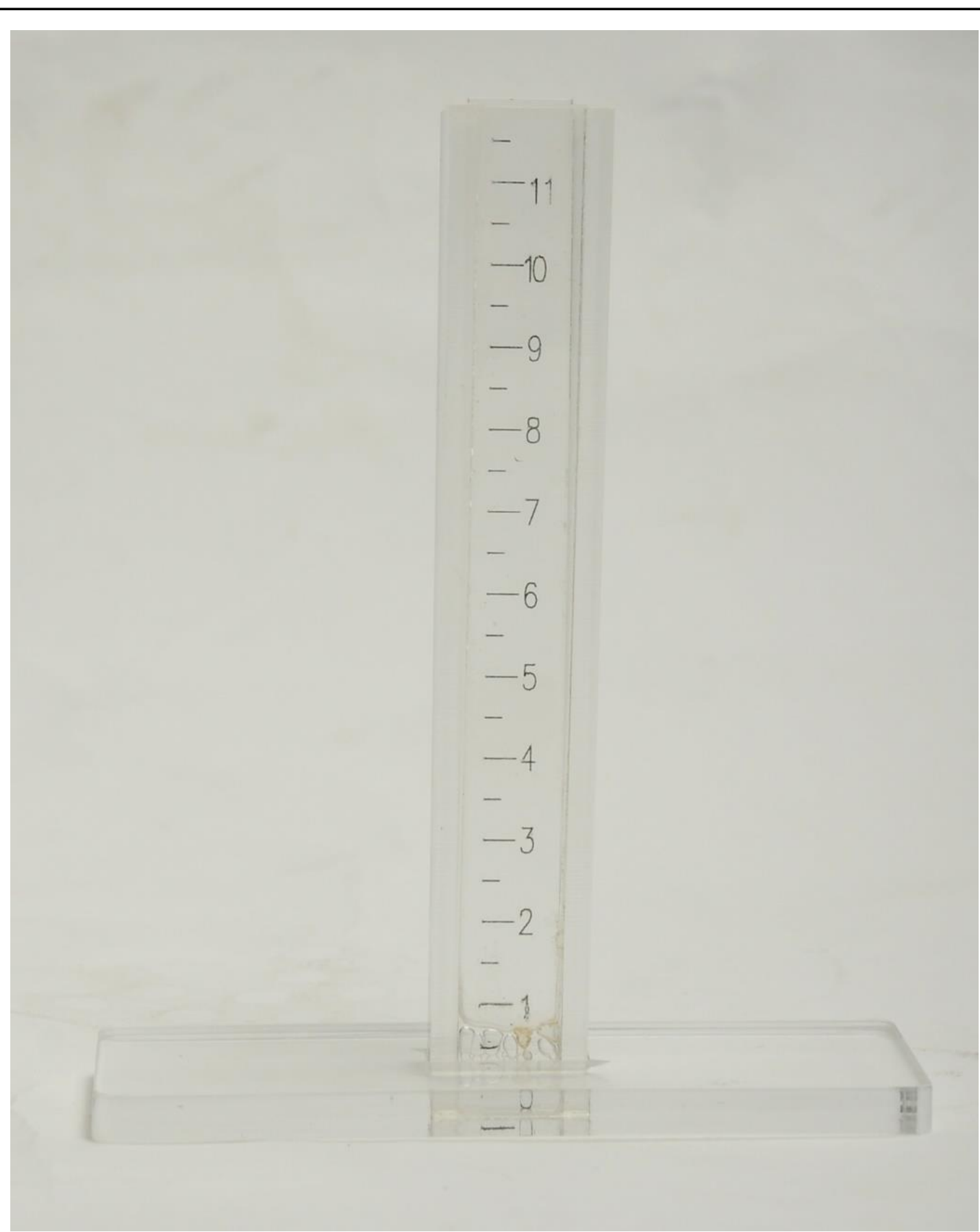

Figure 3 - Empty equine spermdensimeter under artificial light. 


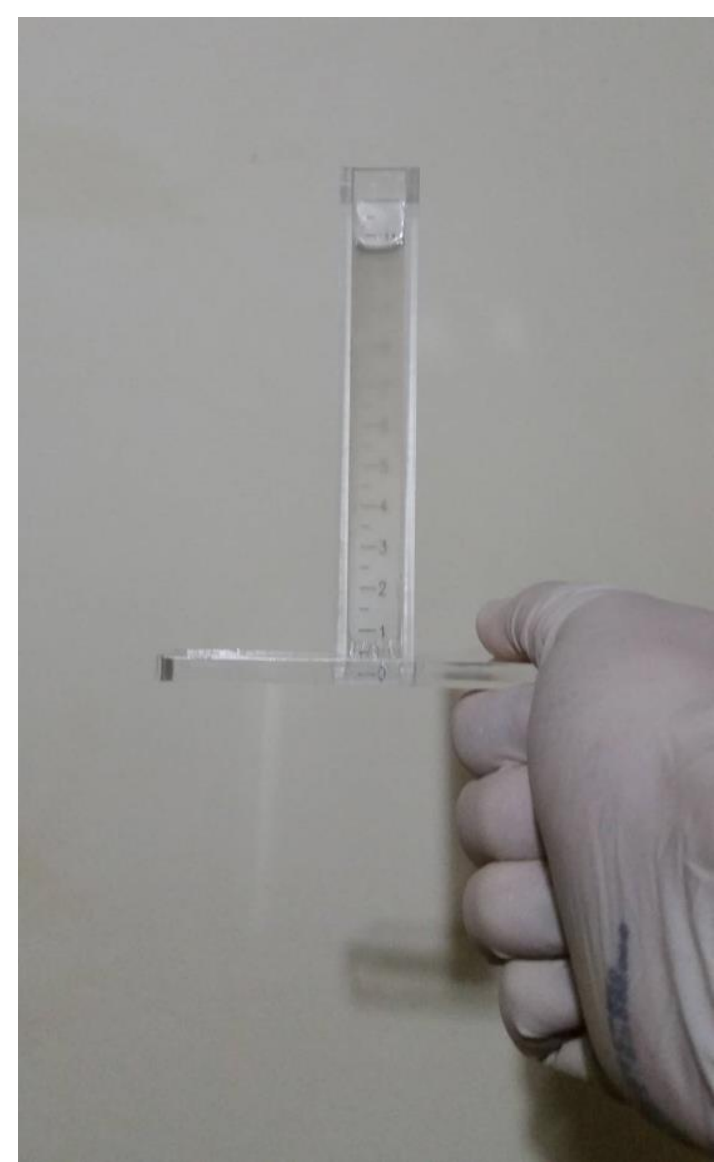

Figure 4 - Spermdensimeter being held against a white wall.

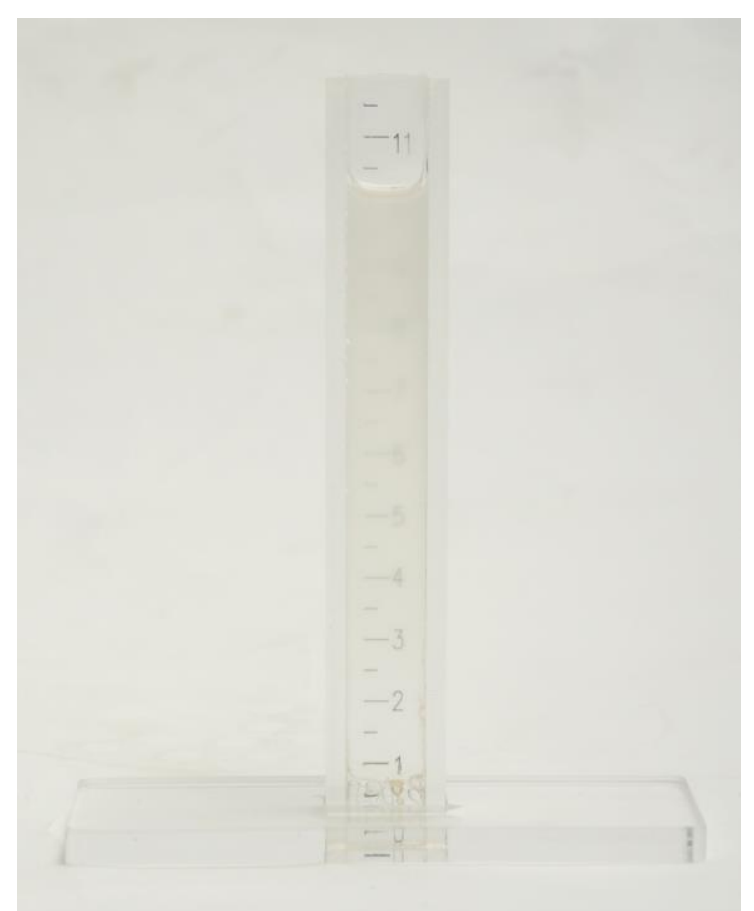

Figure 5 - Equine spermdensimeter with solution turbidity visible at number 5 on the scale under artificial light.

Readings were obtained by two different evaluators for the same samples using both spermdensimeter prototypes in a double-blind study concerning the other evaluator. Moreover, the results were obtained using the standard method (Neubauer chamber), which was performed after the spermdensimeter prototypes were tested. Therefore, two values per spermdensimeter per sample were obtained.

To determine sperm concentrations using the Neubauer chamber, a dilution of 1:20 (1 part of semen to 19 parts of buffered saline and formaldehyde) was made. Five frames on each side of the chamber were counted. We assumed a maximum of $10 \%$ difference between the two sides.

From this, the scale numbers obtained from the spermdensimeter models (mean of the two evaluators) were compared with the measurements from the Neubauer chamber.

Based on semen concentrations determined using the Neubauer chamber, the two spermdensimeters were calibrated. For each model of spermdensimeter, a scale adjustment was made to determine whether the curve of values created was representative and precise. This generated a function from which the concentration table originated.

A linear regression was performed using the least squares method with an exponential model as follows: concentration $=\boldsymbol{a} \cdot \mathbf{e}^{\boldsymbol{b} \cdot \mathbf{s c a l e}}$, where "concentration" corresponds to the reading from the Neubauer chamber, "a" represents the point where the curve intersects the $y$-axis, "scale" is the variation from 1 to 10 displayed on the spermdensimeter, "b" determines its shape, and "e" is the Euler constant 
(value, 2.718281). A priori, a negative "b" value is expected because the function is decreasing.

From the linear regression, a function was generated for each spermdensimeter, and tables were constructed using the function to determine a concentration value for each spermdensimeter scale number. A concentration range for each scale value was also established using interpolation to cover concentration variations within the interval of the function.

The means for the turbidity measurements obtained by the two evaluators for each spermdensimeter was used, and we aimed to correlate the readings from the scales with the values obtained in the corresponding samples in the Neubauer chamber. Pearson's correlation was used to generate a level of significance of $95 \%$. analyses.

Statgraphics Centurion XVI (2009) software was used to perform statistical

\section{RESULTS AND DISCUSSION}

In Figures 6 and 7 , it was observed that the adjustments to the curves were accurate, generating $r^{2}$ values close to 1 . For Model A, $r^{2}$ was equal to 0.9395 , and for Model B, $r^{2}$ was equal to 0.9418 .

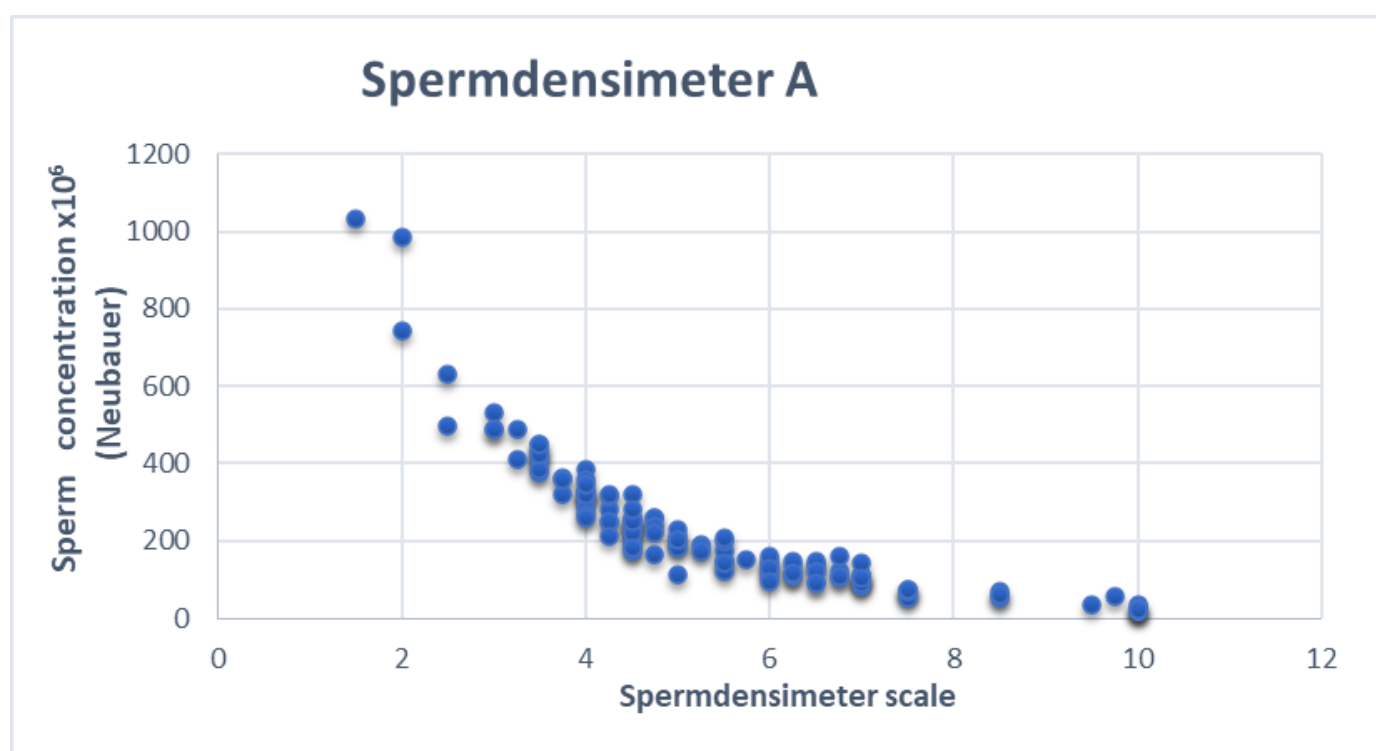

Figure 6 - Linear regression and dispersion of concentration data for equine semen samples obtained using spermdensimeter Model $\mathrm{A}\left(8^{\circ}\right)$ and the Neubauer chamber $(n=123)$. 


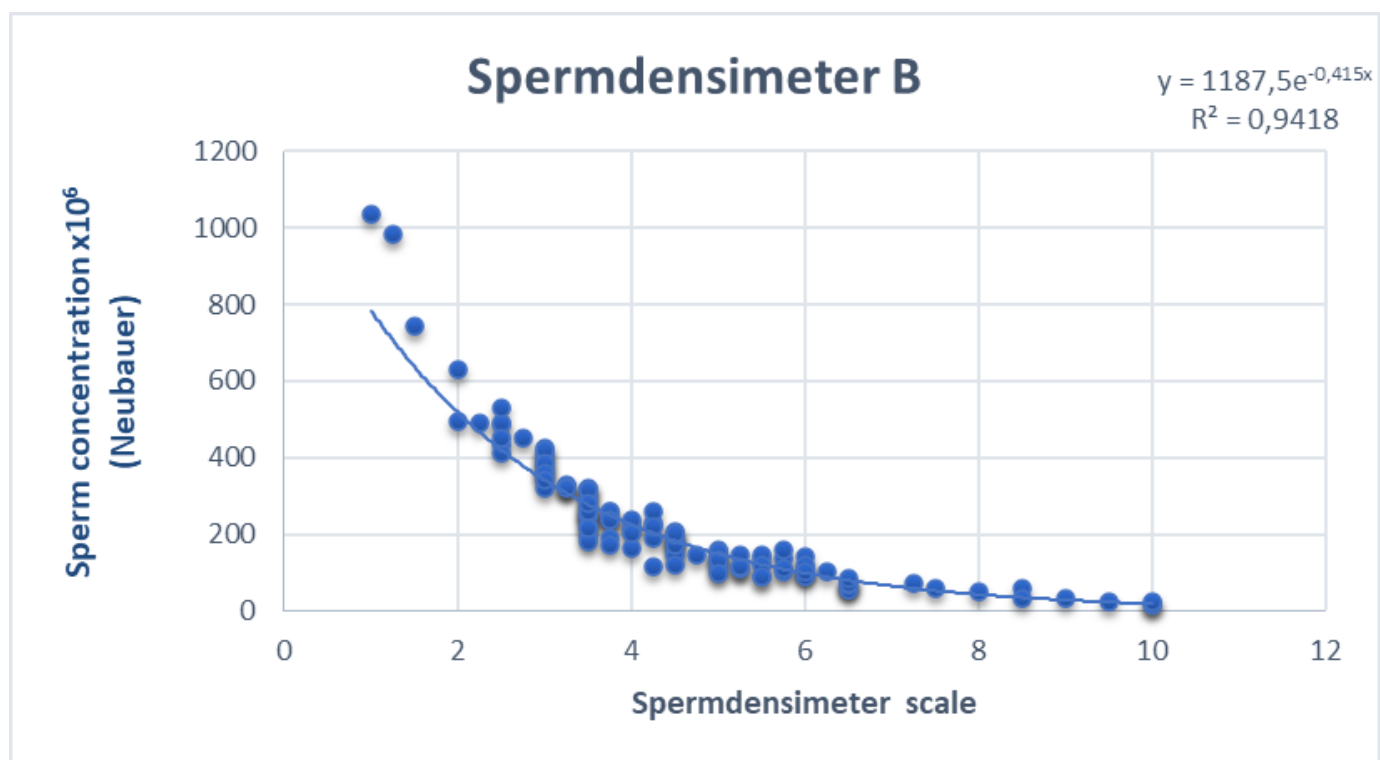

Figure 7 - Linear regression and dispersion of concentration data for equine semen samples obtained using spermdensimeter Model B $\left(10^{\circ}\right)$ and the Neubauer chamber $(n=123)$.

Both spermdensimeter models can be used to effectively perform these measurements, since the $r^{2}$ value close to 1 is an indicator of accuracy for the function adjustment.

Based on the regressions for each model, the data were interpolated so that the concentration values were restricted in maximum and minimum intervals for each point on the scale, as shown in Figures 8 and 9. Since this method does not count sperm cells individually, a variation in each number on the scale was adapted to include concentrations that were between the values of the function. This is because even the objective method (Neubauer chamber) has a tolerance of $10 \%$ for each side, and there are reports of even greater variations (Brazil et al., 2004, Neuwinger et al., 1990). 


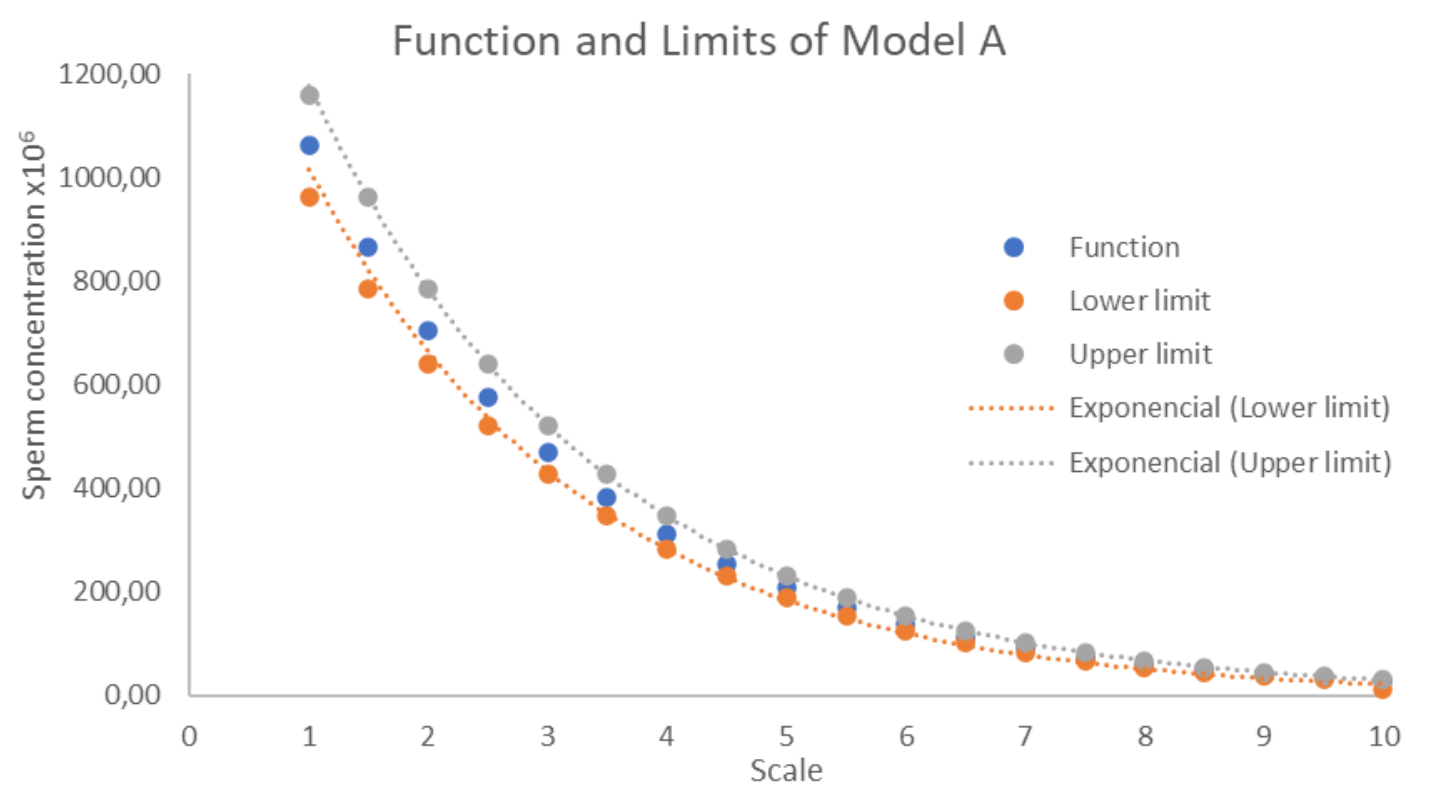

Figure 8 - Lower and upper limits for each linear regression concentration value for equine semen samples measured using spermdensimeter Model $A$ $\left(8^{\circ}\right)$.

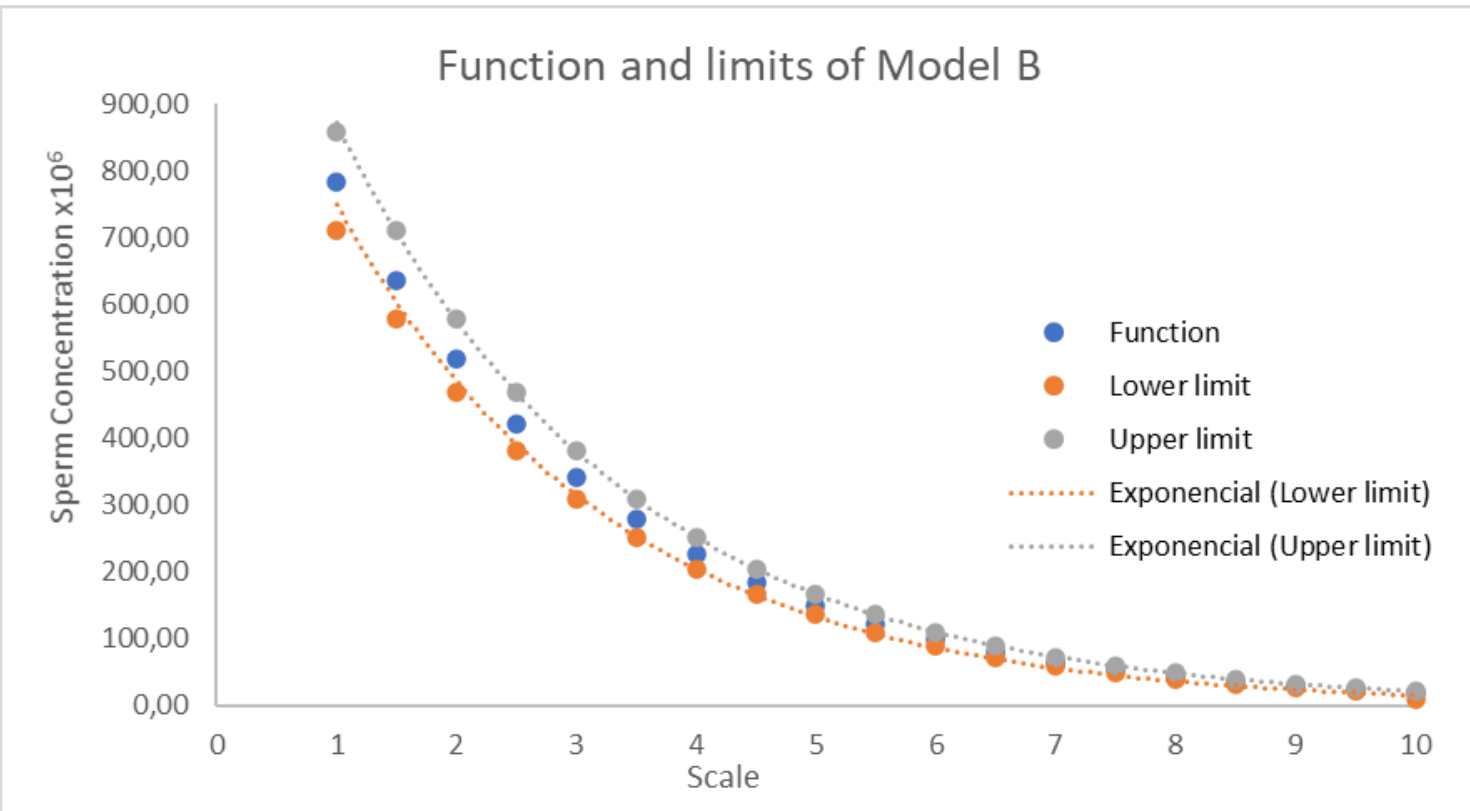

Figure 9 - Lower and upper limits for each linear regression concentration value for equine semen samples measured using spermdensimeter Model B $\left(10^{\circ}\right)$.

Tables 1 and 2 show the mean sperm concentration values $\left(10^{6} / \mathrm{mL}\right)$ obtained by performing linear regression, as well as the lower and upper limits, for each degree of turbidity using each spermdensimeter. 
Table 1 - Sperm concentration values with lower and upper limits for stallions in Model $A\left(8^{\circ}\right)$ spermdensimeter, corresponding to each number on a scale from 1 to $10(n=123)$.

\begin{tabular}{llll}
\hline $\begin{array}{l}\text { Reading } \\
\text { (range } 1-10)\end{array}$ & $\begin{array}{l}\text { Concentration } \\
\left(10^{6} / \mathrm{mL}\right)\end{array}$ & $\begin{array}{l}\text { Lower limit } \\
\left(10^{6} / \mathrm{mL}\right)\end{array}$ & Upper limit $\left(10^{6} / \mathrm{mL}\right)$ \\
\hline 1 & 1061.31 & 963.38 & 1159.23 \\
1.5 & 865.46 & 785.60 & 963.38 \\
2 & 705.75 & 640.63 & 785,60 \\
2.5 & 575.51 & 522.41 & 640.63 \\
3 & 469.31 & 426.00 & 522.41 \\
3.5 & 382.70 & 347.39 & 426.00 \\
4 & 312.08 & 283.28 & 347.39 \\
4.5 & 254.49 & 231.01 & 283.28 \\
5 & 207.53 & 188.38 & 231.01 \\
5.5 & 169.23 & 153.61 & 188.38 \\
6 & 138.00 & 125.27 & 153.61 \\
6.5 & 112.53 & 102.15 & 125.27 \\
7 & 91.77 & 83.30 & 102.15 \\
7.5 & 74.83 & 67.93 & 83.30 \\
8 & 61.02 & 55.39 & 67.93 \\
8.5 & 49.76 & 45.17 & 55.39 \\
9 & 40.58 & 36.84 & 45.17 \\
9.5 & 33.09 & 30.04 & 36.84 \\
10 & 26.98 & 13.49 & 30.04 \\
\hline
\end{tabular}

The scale values in this table correspond to the number obtained from the scale at the back of the spermdensimeter.

The concentration corresponds to the value obtained by linear regression.

The lower and upper limits correspond to the interpolation of the concentration values, showing the values below and above the function, respectively. Thus, each scale value has a specific concentration range. 
Table 2 - Sperm concentration values with lower and upper limits for stallions in Model $\mathrm{B}\left(10^{\circ}\right)$ spermdensimeter, corresponding to each number on a scale from 1 to $10(n=123)$.

\begin{tabular}{llll}
\hline $\begin{array}{l}\text { Reading } \\
\text { (range } 1-10)\end{array}$ & $\begin{array}{l}\text { Concentration } \\
\left(10^{6} / \mathrm{mL}\right)\end{array}$ & $\begin{array}{l}\text { Lower limit } \\
\left(10^{6} / \mathrm{mL}\right)\end{array}$ & Upper limit $\left(10^{6} / \mathrm{mL}\right)$ \\
\hline 1 & 783.82 & 710.38 & 857.26 \\
1.5 & 636.95 & 577.27 & 710.38 \\
2 & 517.59 & 469.10 & 577.27 \\
2.5 & 420.60 & 381.19 & 469.10 \\
3 & 341.79 & 309.76 & 381.19 \\
3.5 & 277.74 & 251.72 & 309.76 \\
4 & 225.69 & 204.55 & 251.72 \\
4.5 & 183.40 & 166.22 & 204.55 \\
5 & 149.04 & 135.07 & 166.22 \\
5.5 & 121.11 & 109.76 & 135.07 \\
6 & 98.41 & 89.19 & 109.76 \\
6.5 & 79.97 & 72.48 & 8919 \\
7 & 64.99 & 58.90 & 72.48 \\
7.5 & 52.81 & 47.86 & 58.90 \\
8 & 42.91 & 38.89 & 47.86 \\
8.5 & 34.87 & 31.60 & 38.89 \\
9 & 28.34 & 25.68 & 31.60 \\
9.5 & 23.03 & 20.87 & 25.68 \\
10 & 18.71 & 9.36 & 20.87 \\
\hline
\end{tabular}

The scale values for this table correspond to the number obtained from the scale at the back of the spermdensimeter.

The concentration corresponds to the value obtained by linear regression.

The lower and upper limits correspond to the interpolation of the concentration values, showing the values below and above the function, respectively. Thus, each scale value has a specific concentration range.

The results of the correlation analysis for the Neubauer chamber versus the readings obtained from Models $A$ and $B$ were -0.83 and -0.8 , respectively (both statistically significant; $p<0.0001)$. These values indicate a large and significantly negative correlation, demonstrating that the higher the concentration, the lower the number obtained from the spermdensimeter scale. Furthermore, the lower the concentration, the higher the number obtained from the spermdensimeter scale.

Despite the spermdensimeter method being subjective, presenting a variation range for each scale number (as demonstrated in Tables 1 and 2) is possible to determine equine sperm concentrations using the prototypes developed. The equine spermdensimeter method proved to be reliable and consistent since the values for estimated concentration were based on the standard method (Neubauer chamber). Thus, the hypothesis of the present study can be confirmed because it was possible to measure stallion sperm concentration with the spermdensimeters developed. 
This study aimed to develop a spermdensimeter able to evaluate stallion sperm concentration including the normal range for the species. The different models used were not compared between them statistically, and the standard method was used for calibration for both models, producing a different scale of concentration for each model. However, Model B seemed to have the turbidity number easier to read for the semen concentrations evaluated (mean: $233.1 \pm 169.4 \times 10^{6}$ sperm cells $/ \mathrm{mL}$ ).

These prototypes are practical and can be employed in the field, making them a viable but subjective alternative to the traditionally used Neubauer chamber, excluding the need for visual counting of the sperm cells. With the spermdensimeters developed in this study, it is possible to perform an immediate dilution of the samples evaluated, right after the ejaculate is collected without the need of a Neubauer chamber or microscope. By estimating the concentration of sperm, it is possible to determine the amount of diluent to be added before using the ejaculate, which should be used according to the concentration and desired purpose, such as cooling, freezing, or inseminating a large number of mares (Conboy, 2011).

Reinforcing the use and consistency of results for sperm quantifications using spermdensimeter method, the Karras spermdensimeter ${ }^{\circledR}$ was compared to the Neubauer chamber and spectrophotometer (Barbosa et al., 2011) using bovine semen. No statistical differences between the Karras spermdensimeter ${ }^{\circledR}$ and Neubauer chamber were observed. In their study, the spermdensimeter was considered to be the best among the three methods, and it was as accurate as the Neubauer chamber. It was also rapid and less expensive than the spectrophotometer or even the Neubauer chamber because cell counting requires a microscope for these traditional quantification methods.

Although consistent with the values obtained using the Neubauer chamber, the mean values obtained using the Karras spermdensimeter ${ }^{\circledR}$ were lower than those obtained with the Neubauer chamber when measuring bovine semen (Barbosa et al., 2011). This is contrary to what has been reported in pigs, for which the spermdensimeter tended to overestimate the concentration of sperm (Vianna et al., 2004, Murgas et al., 2010). Additionally, the spectrophotometer generates statistical disagreements in sperm measurements obtained by various researchers. In some cases, sperm concentrations are overestimated (Murgas et al., 2010), and in others, they are underestimated (Vianna et al., 2004). Sperm concentration overestimation can lead to inseminating doses that have a seminal concentration lower than the recommended standards, leading to reduced fertility (Vianna et al., 2004). This compromises the reproductive efficiency of the herd.

\section{CONCLUSION}

The prototype spermdensimeters (Models $A$ and B) facilitated the measurement of several samples of stallion sperm concentrations in a reliable and consistent way, and evidently, it was easier to perform the readings in Model B than in Model A. Compared to measurements using the Neubauer chamber, the equine spermdensimeters developed accurately estimate the concentration of sperm in semen in the field conditions, excluding the need of a microscope and the visual counting of sperm cells. Due to the subjectivity of the method, sperm concentration obtained with spermdensimeters is not precise, presenting a range of variation. Further studies should be conducted to compare the two models with other methods used for evaluating equine sperm concentration. 
Note: The models developed in the present study are protected by the Invention Patent with Instituto Nacional da Propriedade Industrial of Brazil (INPI/BR) deposited on August 17, 2016 under the number BR 102016019032 0, according to national guidelines.

\section{ACKNOWLEDGMENTS}

The authors thank Professors Marco Flávio Mattana from Pontifícia Universidade Católica of Paraná for the photographs of the spermdensimeters, Dr. Saulo Henrique Weber for his help with statistical analysis, and Pontifícia Universidade Católica of Paraná for the scholarship granted. This study did not receive any specific grant from any funding agency in public, commercial, or not-forprofit sector.

\section{APPROVAL OF THE ETHICS COMMITTEE}

Pontifical Catholic University of Paraná, number 898.

\section{CONFLICT OF INTEREST}

None of the authors have any conflict of interest to declare.

\section{REFERENCES}

BARBOSA, C.P.; OLIVEIRA, W.C.; RIBEIRO JÚNIOR, W.R. Comparação entre as principais técnicas de análise da concentração espermática em exames andrológicos de touros a campo. PUBVET, 5, art.1100, 2011.

BRAZIL, C.; SWAN, S.H.; TOLLNER, C.R. et al. 2004 Quality control of laboratory methods for semen evaluation in a multicenter research study. Journal of Andrology, v.25, p.645-656, 2004. doi 10.1002/j.1939-4640.2004.tb02836.x

COLÉGIO BRASILEIRO DE REPRODUÇÃO ANIMAL - CBRA. Manual para exame andrológico e avaliação de sêmen animal. 2nd ed. Belo Horizonte: CBRA, 1998. 49p.

CONBOY, H.S. Management of stallions in artificial insemination. In: McKINNON, A.O.; SQUIRES, E.L.; VAALA, W.E.; VARNER, D.D. Equine reproduction. 2nd ed. lowa: Blackwell, 2011, p.1198-1207.

ESTRADA, A.J.; SAMPER, L.C. Evaluation of raw semen. In: SAMPER, J.C., PYCOCK, J.F., McKINNON, A.O. Current therapy in equine reproduction. St. Louis: Saunders, 2007, p.253-57.

GARNER, D.L., HAFEZ, E.S.E. Espermatozóides e plasma seminal. In: HAFEZ E.S.E; HAFEZ B. Reprodução animal. 7th ed. Barueri: Manole, 2004, p.97-110. GRIFFIN, P.G. The breeding soundness examination in the stallion. Journal of Equine Veterinary Science. v.20, p.168-171, 2000. doi 10.1016/S07370806(00)80129-X

GUASTI, P.N.; MONTEIRO, G.A.; PAPA, F.O. Componentes do plasma seminal e sua influência sobre a criopreservação e fertilidade espermática de equinos. Veterinária e Zootecnia. v.19, p.169-180, 2012.

LOVE, C.C. Reproductive examination of the stallion: evaluation of potential breeding soundness. In: YOUNGQUIST RS; THARELFALL WR. Current therapy in large animal. Theriogenology. 2nd ed. Saint Louis: Elsevier-Saunders, 2007, p.10-14.

MURGAS, L.D.S. LIMA, D.; ALVARENGA, A.L.N. et al. Estudo comparativo de diferentes técnicas de avaliação da concentração espermática em suínos. Archivos de Zootecnia, v.59, n.227, p.463-466, 2010. 
NATH, L.C. Reproductive efficiency. In: McKINNON, A.O., SQUIRES, E.L., VAALA, W.E., VARNER, D.D. Equine reproduction. 2nd ed. v.2. lowa: Wiley Blackwell, 2011, p.2779-2789.

NEUWINGER, J.; BEHRE, H.M.; NIESCHLAG, E. External quality control in the andrology laboratory: An experimental multicenter trial. Fertility and Sterility, v.54, p.308-14, 1990. doi 10.1016/S0015-0282(16)53709-1

NOAKES, D.E.; ARTHUR, G.H.; PARKINSON, T.J. et al. Arthur's veterinary reproduction and obstetrics, 8th ed. Philadelphia: W.B. Saunders, 2001.

NUNES, D.B.; ZÚCCARI, C.S.R.N.; COSTA, E.V. et al. Fatores relacionados ao sucesso da inseminação artificial de éguas com sêmen refrigerado. Revista Brasileira de Reprodução Animal, v.30, p.42-56, 2006.

VIANNA, W.L.; BRUNO, D.G.; NAMINDOME. A. et al. Estudo comparativo da eficiência de diferentes técnicas de mensuração da concentração espermática em suínos. Revista Brasileira Zootecnia. v.33, p.2054-2059, 2004. doi 10.1590/S1516$\underline{35982004000800017}$ 